\title{
ANALISIS PERSEPSI MAHASISWA IKIP PGRI MADIUN TERHADAP PANCASILA SEBAGAI IDENTITAS NASIONAL
}

\author{
Budiyono dan Wawan Kokotiasa *
}

\begin{abstract}
Abstrak
Globalisasi membawa dampak pada kehidupan sosial, ekonomi, politik, budaya idiologi, bangsa dan negara Indonesia. Dari berbagai media masa mensinyalir bahwa pengaruh globalisasi telah merasuki pola pikir bangsa Indonesia, diantaranya pada generasi muda yang mulai memudar pemahamannya pada identitas nasionalnya yaitu Pancasila. Berdasarkan sinyalemen tersebut, menarik untuk meneliti Mahasiswa sebagai bagian dari generasi muda sejauhmana pandangannya terhadap Pancasila sebagai Identitas Nasional.

Tujuan penelitian ini untuk menggali persepsi mahasiswa IKIP PGRI Madiun terhadap Pancasila sebagai identitas nasional dan mengetahui makna Pancasila sebagai identitas nasional

Prosedur penelitian penelitian ini menggunakan metode kualitatif, teknik pengumpulan data dengan observasi dan wawancara, subjek penelitian ini adalah mahasiswa IKIP PGRI Madiun yang diambil secara proporsional. Analisis data dilakukan melalui analisis interaktif.

Hasil penelitian mayoritas persepsi mahasiswa tentang eksistensi Pancasila cukup baik, terbukti mahasiswa telah mengetahui dengan jelas sila-sila dalam Pancasila. Bahkan diantara mereka ada yang dapat menjelaskan lebih lanjut tantang fungsi dan peran Pancasila bagi bangsa dan negara Indonesia.

Sebagian besar mahasiswa menganggap penting Pancasila sebagai perekat keutuhan atau pemersatu NKRI. Pancasila sebagai identitas nasional merupakan ciri khas yang hanya dimiliki bangsa Indonesia yang membedakan dengan bangsa lain, oleh karena itu Pancasila harus dilestarikan.

Makna Pancasila sebagai identitas nasional merupakan sesuatu yang amat penting dan strategis bagi eksistensi bangsa Indonesia dalam percaturan global, tanpa Pancasila sebagai identitas nasional bangsa Indonesia akan kehilangan jati diri nya sebagai bangsa besar dan majemuk.
\end{abstract}

Kata kunci : Pancasila, Identitas Nasional

*Dosen Prodi PPKn IKIP PGRI Madiun 


\section{BAB I}

\section{PENDAHULUAN}

\section{A. Latar Belakang Masalah}

Identitas nasional suatu bangsa menjadi penting, ketika globalisasi tengah melanda negara bangsa, bangsa yang tidak kuat dalam mempertahankan jatidirinya akan terombang ambing oleh derasnya arus globalisasi yang dapat berdampak pada krisis jati diri atau identitas nasionalnya.

Globalisasi adalah suatu keniscayaan yang tidak dapat dihindari, karena pesatnya kemajuan teknologi informasi dan komunikasi, yang membawa proses penciptaan dan pengintegrasian ekonomi dibawah hegemoni kapitalis. Semangat globalisasi adalah perdagangan bebas untuk barang dan jasa, kebebasan sirkulasi kapital, serta kebebasan investasi, kemudian merambah ke bidang-bidang kehidupan lain sehingga globalisasi menjadi proses transformasi global yang makin nyata di pelbagai bidang (idiologi, politik, budaya, ekonomi).

$$
\text { Seiring dengan besarnya kran }
$$
kebebasan semenjak era reformasi, bangsa
Indonesia tidak dapat terlepas dari berbagai pengaruh dari luar, termasuk bidang idiologi, politik, budaya, ekonomi, yang di 'adopsi ' begitu saja oleh para elit politik, yang nampak cara berpikir dan bertindak cenderung meniru-niru apa saja yang datang dari barat, untuk menyelesaikan persoalan krisis multi dimensi yang tengah melanda bangsa Indonesia, namun realitasnya malah menimbulkan persoalan baru yang makin kompleks, diantaranya radikalisme agama, pudarnya nilai toleransi antar umat beragama, dan semangat gotong royong, menguatnya isu etnisitas berbau SARA, kesenjangan sosial ekonomi, lunturnya Pancasila di dada generasi muda (Republika 27/5/2011), dan yang paling mengkhawatirkan adalah isu NII yang menyeret mahasiswa di berbagai perguruan tinggi, dengan metode mencuci otak mereka.

Berbagai persoalan yang tengah melilit bangsa tersebut, bila dicermati secara mendalam, nampak bahwa akar permasalahannya terletak pada semakin pudarnya nilai-nilai Pancasila sebagai identitas nasional terutama pada generasi muda. Apabila tidak segera ditemukan solusi atas problematika tersebut dan memudarnya 
penghayatan nilai-nilai Pancasila, secara perlahan stabilitas negara Indonesia akan terganggu bahkan bisa menuju ke disintegrasi bangsa. Sri Edi Swasono, (Kompas 8/6/2011), mengingatkan bahwa bangsa Indonesia perlu pegangan identitas nasional, yaitu Pancasila:

“ ada benarnya sebagian dari kita menegaskan bahwa disamping merupakan nilai budaya, identitas bangsa, filsafat negara, dan idiologi nasional, Pancasila adalah platform nasional yang dengan penuh toleransi diterima semua agama sebagai konsensus nasional. Pancasila adalah paham persatuan sekaligus kebijakan nasional untuk mempertahankan persatuan. berdasarkan platform ini, persatuan bukanlah sekedar persatean. Tanpa platform nasional bangsa ini akan ela elo, mudah terombang ambing tanpa pegangan, akan dilanda kebingungan, berjalan tanpa pedoman arah dalam mempertahankan kemerdekaan nasional yang kita miliki sejak proklamasi kemerdekaan 1945".

Lebih lanjut, Muhammad Noor Syam (Media Indonesia 1/10/2010) menegaskan :

"Ajaran dan nilai filsafat amat mempengaruhi pikiran, budaya dan peradaban, serta moral manusia. semua sistim kenegaraan ditegakkan berdasarkan ajaran atau sistim filsafat yang mereka anut (sebagai dasar negara, ideologi negara)... berbagai negara modern mempromosikan keunggulan masing-masing, dan terus memperjuangkan supremasi idiologi dan dominasi sistim kenegaraannya: theokratisme, liberalisme, kapitalisme, marxisme, komunisme-atheisme... bangsa Indonesia menegakkan sistim kenegaraan Pancasila,UUD Proklamsi 45 sebagai aktualisasi filsafat hidup yang diamanatkan oleh Panitia Persiapan Kemerdekaan Indonesia (PPKI) sebagai pendiri negara."

Berkaitan dengan permasalahan diatas, menarik untuk mengetahui sejauh mana persepsi mahasiswa terhadap Pancasila sebagai identitas nasional, karena mereka dengan jiwa progresifnya, sebagai generasi muda memiliki potensi strategis untuk menyongsong estafet kepemimpinan bangsa di masa mendatang. Kedepan, tegak / berjaya atau hancurnya bangsa Indonesia tergantung pada generasi muda ini. Dengan pandangan yang kuat atau kokoh terhadap identitas nasionalnya bangsa dan negara Indonesia akan berdiri tegak tidak mudah terombang-ambing. Sebaliknya bila persepsi mereka terhadap identitas nasionalnya lemah, bangsa dan negara Indonesia akan menjadi bulan-bulanan negara lain.

Karena itu hasil penelitian ini diharapkan mampu memberikan gambaran 
yang komprehensif, persepsi mahasiswa IKIP PGRI Madiun terhadap identitas nasional yaitu Pancasila, dalam upaya meneguhkan jati diri bangsa Indonesia ditengah percaturan dunia yang penuh persaingan.

\section{B. Rumusan Masalah}

Berdasarkan latar belakang tersebut, maka masalah penelitian dapat dirumuskan sebagai berikut :

1. Bagaimana persepsi mahasiswa IKIP PGRI Madiun Terhadap Pancasila sebagai identitas nasional ?

2. Apakah makna Pancasila sebagai identitas nasional bagi mahasiswa IKIP PGRI Madiun?

\section{Tujuan Penelitian}

Tujuan penelitian ini secara spesifik untuk mengetahui :

1. Menggali persepsi atau pandangan mahasiswa IKIP PGRI Madiun terhadap Pancasila sebagai identitas nasional.
2. Mengetahui makna pancasila sebagai identitas nasional di kalangan mahasiswa khususnya di IKIP PGRI Madiun

\section{Manfaat Penelitian}

1. Dengan mengetahui pandangan mahasiswa IKIP PGRI Madiun terhadap Pancasila sebagai identitas nasional, maka akan dapat bermanfaat untuk pengembangan bahan pembelajaran pendidikan Pancasila.

2. Menambah wawasan baik secara teoritis maupun praksis terhadap makna Pancasila sebagai identitas nasional dalam kehidupan bermasyarakat, berbangsa dan bernegara 
BAB II

\section{KAJIAN PUSTAKA}

\section{A. Identitas Nasional}

Kata identitas berasal dari bahasa Inggris, yaitu identity yang memiliki pengertian harfiah ciri-ciri, tanda-tanda atau jati diri yang melekat pada seseorang atau sesuatu yang membedakannya dengan yang lain. Dalam term antropologi, identitas adalah sifat khas yang menerangkan dan sesuai dengan kesadaran diri pribadi sendiri, golongan sendiri, kelompok sendiri atau negara sendiri. Sedangkan kata nasional merupakan identitas yang melekat pada kelompok-kelompok yang lebih besar yang diikat oleh kesamaan-kesamaan baik fisik seperti budaya, agama, dan bahasa maupun non fisik seperti keinginan, cita-cita dan tujuan. Himpunan kelompok-kelompok inilah yang kemudian disebut dengan istilah identitas bangsa atau identitas nasional yang pada akhirnya melahirkan tindakan kelompok yang diwujudkan dalam bentuk organisasi atau pergerakan yang diberi atribut-atribut nasional.(Heri Herdiawanto dan Jumanta Hamdayama, 2010)
Identitas nasional Indonesia

merupakan manifestasi nilai-nilai budaya yang tumbuh dan berkembang dalam berbagai aspek kehidupan dari ratusan suku yang dihimpun dalam satu kesatuan Indonesia menjadi kebudayaan nasional dengan acuan Pancasila dan Bhinneka Tunggal Ika, sebagai dasar dan arah pengembangannya. Nilai-nilai budaya yang tercermin dalam identitas nasional bukanlah barang jadi yang telah selesai dalam kebekuan normatif dan dogmatis, melainkan sesuatu yang terbuka yang cenderung terus menerus bersemi karena adanya hasrat menuju kemajuan yang dimiliki oleh masyarakat pendukungnya. konsekuensi dan implikasinya adalah identitas nasional merupakan sesuatu yang terbuka untuk ditafsir dengan diberi makna baru agar tetap relevan dan fungsional dalam kondisi aktual yang berkembang dalam masyarakat.

Identitas nasional itu bersifat buatan karena dibuat, dibentuk dan disepakati oleh warga bangsa sebagai identitasnya setelah mereka bernegara dan bersifat sekunder disebabkan identitas nasional itu lahir belakangan bila dibandingkan identitas 
kesukubangsaan yang telah dimiliki warga bangsa itu secara askriptif (ada sejak lahir).

Menurut Heri Herdiawanto dan Jumanta (2010), Identitas nasional Indonesia merujuk pada suatu bangsa yang majemuk. Kemajemukan itu merupakan gabungan unsur -unsur pembentuk identitas yaitu sebagai berikut :

1) Suku Bangsa: golongan sosial yang khusus yang bersifat askriptif (ada sejak lahir), yang sama coraknya dengan golongan umur dan jenis kelamin. Di Indonesia terdapat banyak sekali suku bangsa atau kelompok etnis dengan tidak kurang tiga ratus dialek bahasa.

2) Agama: bangsa Indonesia dikenal sebagai masyarakat yang agamis. Agama-agama yang tumbuh dan berkembang di nusantara adalah agama Islam, Kristen, Katholik, Hindu, Budha dan Kong $\mathrm{Hu} \mathrm{Cu}$. Agama Kong $\mathrm{Hu} \mathrm{Cu}$ pada masa orde baru tidak diakui sebagai agama resmi negara, namun sejak pemerintahan Presiden Abdurrahman Wahid, istilah agama resmi negara dihapuskan.
3) Kebudayaan: pengetahuan manusia sebagai makhluk sosial yang isinya adalah perangkat-perangkat atau model-model pengetahuan yang secara kolektif digunakan oleh pendukung-pendukungnya untuk menafsirkan dan memahami lingkungan yang dihadapi dan digunakan sebagai rujukan atau pedoman untuk bertindak (dalam bentuk kelakuan dan benda-benda kebudayaan) sesuai dengan lingkungan yang dihadapi.

4) Bahasa: unsur pendukung identitas nasional yang lain. Bahasa dipahami sebagai sistem perlambang yang secara arbiter dibentuk atas unsurunsur bunyi ucapan manusia dan digunakan sebagai sarana berinteraksi antar manusia.

Identitas nasional merupakan pandangan hidup bangsa, kepribadian bangsa, filsafat Pancasila dan juga sebagai ideologi negara sehingga mempunyai kedudukan paling tinggi dalam tatanan kehidupan berbangsa dan bernegara, termasuk dalam tatanan hukum yang berlaku di Indonesia. Dalam arti lain sebagai dasar negara yang merupakan 
norma peraturan yang harus dijunjung tinggi oleh semua warganegara, yang mengatur hak dan kewajiban warganegara, demokrasi, hak asasi manusia yang makin berkembang. Hal inilah akhirnya menjadi etika politik kemudian dikembangkan menjadi konsep geopolitik dan geostrategi ketahanan nasional Indonesia. Muatan dan unsur-unsur identitas
nasional dapat digambarkan sebagai
berikut:

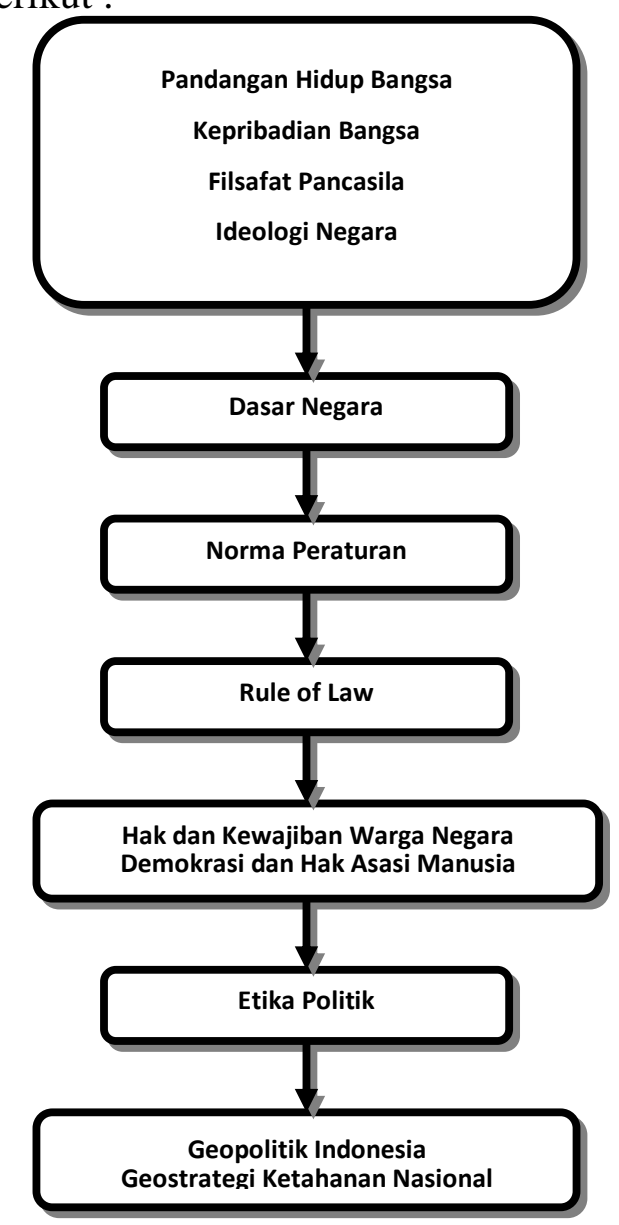

Bagan 1 : Muatan Unsur-unsur identitas nasional

Setelah bangsa Indonesia bernegara mulai dibentuk dan disepakati apa-apa yang menjadi identitas nasional Indonesia, Winarno (2010) adalah sebagai berikut ;

1. Bahasa nasional atau bahasa persatuan yaitu bahasa Indonesia

2. Bendera negara yaitu sang merah putih

3. Lagu kebangsaan yaitu Indonesia raya

4. Lambang negara yaitu Garuda Pancasila

5. Semboyan negara yaitu Bhinneka Tunggal Ika

6. Dasar falsafah negara yaitu Pancasila

7. Konstitusi negara yaitu UUD 1945

8. Bentuk negara kesatuan republik Indonesia

9. Konsepsi wawasan nusantara

10. Kebudayaan daerah yang telah diterima sebagai kebudayaan nasional.

Sedangkan menurut Parji (2010) beberapa bentuk identitas nasional Indonesia yang perlu terus dipelihara dan ditingkatkan adalah sebagai berikut : 
a. Bahasa nasional atau bahasa persatuan yaitu bahasa Indonesia.

Bahasa Indonesia berawal dari rumpun bahasa Melayu yang dipergunakan sebagai bahasa pergaulan yang kemudian diangkat sebagai bahasa persatuan pada tanggal 28 Oktober 1928. Bangsa Indonesia sepakat bahwa bahasa Indonesia merupakan bahasa nasional sekaligus sebagai identitas nasional Indonesia.

b. Dasar falsafah negara yaitu Pancasila. Berisi lima nilai dasar yang dijadikan sebagai dasar filsafat dan ideologi dari negara Indonesia. Pancasila merupakan identitas nasional yang berkedudukan sebagai dasar negara dan ideologi nasional Indonesia.

c. Lagu Kebangsaan yaitu Indonesia Raya. Indonesia Raya sebagai lagu kebangsaan pada tanggal 28 Oktober 1928 dinyanyikan untuk pertama kali sebagai lagu kebangsaan negara.

d. Lambang Negara yaitu Garuda Pancasila. Garuda adalah burung khas Indonesia yang dijadikan lambang negara.

e. Semboyan negara yaitu Bhinneka Tunggal Ika
Bhinneka Tunggal Ika artinya berbeda-beda tetapi tetap satu jua. Menunjukkan kenyataan bahwa bangsa kita heterogen, namun tetap berkeinginan untuk menjadi satu bangsa yaitu bangsa Indonesia.

f. Bendera negara yaitu Sang Merah Putih. Warna merah berarti berani dan putih berarti suci. Lambang merah putih sudah dikenal pada masa kerajaan di Indonesia yang kemudian diangkat sebagai bendera negara. Bendera wama merah putih dikibarkan pertama kali pada tanggal 17 Agustus 1945, namun telah ditunjukkan pada peristiwa Sumpah Pemuda.

g. Konstitusi (Hukum Dasar) negara yaitu UUD 1945

Merupakan hukum dasar tertulis yang menduduki tingkatan tertinggi dalam tata urutan perundangan dan dijadikan sebagai pedoman penyelenggaraan bernegara.

h. Bentuk Negara Kesatuan Republik Indonesia yang berkedaulatan rakyat.

Bentuk negara adalah kesatuan, sedang bentuk pemerintahan adalah Republik. Sistem politik yang digunakan adalah sistem demokrasi (kedaulatan rakyat). 
Saat ini identitas Negara Kesatuan

Republik Indonesia yang berkedaulatan rakyat disepakati untuk tidak ada perubahan.

\section{i. Konsepsi Wawasan Nusantara}

Sebagai cara pandang bangsa Indonesia mengenai diri dan lingkungannya yang serba beragam dan memiliki nilai strategis dengan mengutamakan persatuan dan kesatuan bangsa, kesatuan wilayah dalam penyelenggaraan kehidupan bermasyarakat, berbangsa, dan bernegara untuk mencapai tujuan nasional.

j. Kebudayaan daerah yang telah diterima sebagai kebudayaan nasional.

Berbagai kebudayaan dari kelompokkelompok bangsa Indonesia yang dimiliki cita rasa tinggi, dapat dinikmati dan diterima oleh masyarakat luas merupakan kebudayaan nasional. Kebudayaan nasional pada dasarnya adalah puncak dari kebudayaan daerah.

Tumbuh dan disepakatinya beberapa identitas nasional Indonesia itu sesungguhnya telah diawali dengan adanya kesadaran politik bangsa Indonesia sebelum bernegara. Hal demikian sesuai dengan ciri dari pembentukan negara model mutakhir.
Kesadaran politik itu adalah tumbuhnya semangat nasionalisme (semangat kebangsaan) sebagai gerakan menentang penjajahan dan mewujudkan negara Indonesia. Dengan demikian, nasionalisme yang tumbuh kuat dalam diri bangsa Indonesia turut mempermudah terbentuknya identitas nasional Indonesia.

Paham nasionalisme atau paham kebangsaan adalah sebuah situasi kejiwaan dimana kesetiaan seseorang secara total diabdikan langsung kepada negara bangsa atas nama sebuah bangsa. Munculnya nasionalisme terbukti sangat efektif sebagai alat perjuangan bersama merebut kemerdekaan dari cengkeraman kolonial.

Identitas nasional Indonesia merujuk pada suatu bangsa yang majemuk. Kemajemukan itu merupakan gabungan dari unsur-unsur pembentuk identitas yaitu suku bangsa, agama, kebudayaan dan bahasa.

Menurut Syarbani (2011) Identitas Nasional Indonesia dapat dirumuskan menjadi tiga bagian : 
1. Identitas fundamental yaitu Pancasila yang merupakan falsafah bangsa, dasar negara, idiologi negara.

2. Identitas instrumental berisi UUD 45 dan tata perundangannya bahasa Indonesia, lambang negara, bendera negara, lagu kebangsaan Indonesia raya

3. Identitas alamiah meliputi negara kepulauan dan pluralisme dalam suku, bahasa, budaya, dan agama serta kepercayaan.

Identitas nasional pada hakikatnya merupakan "manifestasi nilai-nilai budaya yang tumbuh dan berkembang dalam aspek kehidupan suatu nation (bangsa) dengan ciri-ciri khas, dan dengan ciri-ciri yang khas tadi suatu bangsa berbeda dengan bangsa lain dalam hidup dan kehidupannya" (Wibisono Koento: 2005).

Dapat disimpulkan bahwa yang menjadi identitas nasional utama bagi negara-bangsa Indonesia adalah Pancasila, alat pemersatu untuk di atasnya diletakkan Negara Kesatuan Republik Indonesia.

\section{B. Tinjauan tentang Pancasila}

Istilah Pancasila berasal dari bahasa Sansekerta yang terdiri dari dua suku kata yaitu Panca berarti lima dan sila berarti dasar atau azas. Pancasila berarti lima dasar atau lima azas. Diatas lima dasar inilah berdirinya Negara Republik Indonesia. Pancasila dipilih menjadi dasar negara karena Pancasila sesuai dengan alam kejiwaan bangsa kita sendiri, seperti apa yang pernah dikatakan oleh Bung Karno “ sudah jelas kalau kita mau mencari dasar yang statis, maka dasar yang statis itu haruslah terdiri dari elemen-elemen yang ada jiwa Indonesia" Ernest Renan mengatakan bahwa "setiap bangsa mempunyai suatu jiwa “ (une nation, est une ame). Bangsa Indonesia mempunyai satu jiwa yang disebut kepribadian bangsa Indonesia. Tegasnya Pancasila adalah manifestasi dari kepribadian bangsa Indonesia. Disamping itu Pancasila merupakan tuntunan yang dinamis, seperti Bung Karno menyebutkan sebagai "leidster" bintang pimpinan, kearah mana bangsa dan negara Indonesia harus digerakkan. 
Dalam sidang BPUPKI pada tanggal 1 Juni, Bung Karno merumuskan Pancasila, yang dikenal juga sebagai pidato lahirnya Pancasila, dan mengusulkan agar negara Indonesia yang akan didirikan itu ditegakkan diatas kelima sila yang telah digalinya itu, dengan suara bulat sidang menerima Pancasila sebagai dasar negara yang kekal abadi yang oleh Bung Karno sendiri disebut philosophis grondslag, dengan rumusan sebagai berikut :

1. Kebangsaan Indonesia

2. Internasionalisme atau perikemanusiaan

3. Mufakat atau demokrasi

4. Kesejahteraan sosial

5. Ketuhanan Yang Maha Esa

Kemudian BPUPKI menugaskan panitia 9 untuk menyusun rancangan pembukaan undang undang dasar pada tanggal 22 Juni 1945. Pada alenia 4 dari rancangan pembukaan undang undang dasar tersebut dicantumkan Pancasila dengan rumusan (piagam jakarta) sebagai berikut :

1. Ketuhanan dengan kewajiban menjalankan syariat Islam bagi pemeluk pemeluknya.

2. Kemanusiaan yang adil dan beradab
3. Persatuan Indonesia

4. Kerakyatan yang dipimpin oleh hikmat kebijaksanaan dalam permusyawaratan dan perwakilan

5. Keadilan sosial bagi seluruh rakyat Indonesaia

Rumusan Pancasila sebagai dasar negara dan sebagai platform demokratis berbagai golongan khususnya dari kaum kebangsaan dan Islam. Pancasila ditrasformasikan menjadi konsep politik dalam konteks pemikiran politik Indonesia sebagai dasar negara berisi lima prinsip. Pancasila yang diakui pemerintah secara resmi rumusannya berbunyi sebagai berikut:

1. Ketuhanan Yang Maha Esa

2. Kemanusiaan Yang Adil dan Beradab

3. Persatuan Indonesia

4. Kerakyatan Yang Dipimpin oleh Hikmat Kebijaksanaan dalam Permusyawaratan Perwakilan

5. Keadilan Sosial bagi Seluruh Rakyat Indonesia

Pancasila sebagai dasar filsafati negara Indonesia pada hakekatnya merupakan suatu nilai-nilai yang bersifat sistematis. Sebagai suatu dasar filsafat, silasila dalam Pancasila atau kelima sila yang 
ada di dalamnya merupakan suatu sistim yaitu merupakan satu kesatuan yang bulat, hierarkis dan sistematis, maka kelima sila bukan terpisah pisah melainkan memiliki makna yang utuh yang merupakan sistim nilai (Kaelan,2008). Hal ini sesuai dengan pengertian sebelumnya bahwa dasar negara terkandung didalamnya seperangkat nilai. Pancasila berisi lima nilai yang merupakan nilai dasar fundamental bagi kehidupan berbangsa dan bernegara yaitu nilai Ketuhanan, Kemanusiaan, Persatuan, Kerakyatan, dan nilai keadilan. Nilai-nilai Pancasila merupakan rumusan ideal, bersifat das sollen dan cita-cita yang harus diwujudkan dalam kenyataan.

\section{Kedudukan dan Fungsi Pancasila}

Pancasila memiliki kedudukan dan fungsi yang sangat penting dan strategis bagi berdiri dan tegaknya negara Kesatuan Republik Indonesia. Atau dengan kata lain untuk mendirikan bangunan negara Indonesia yang kekal dan abadi harus diatas fundamen yang kuat dan kokoh yang dapat mengikat dan mempersatukan elemenelemen masyarakat, yaitu Pancasila.
Pancasila sebagai objek pembahasan ilmiah memiliki ruang lingkup yang sangat luas terutama berkaitan dengan kedudukan dan fungsi Pancasila. Setiap kedudukan dan fungsi Pancasiia pada hakikatnya memiliki makna serta dimensi masing-masing yang konsekuensinya aktualisasinyapun juga memiliki aspek yang berbeda-beda, walaupun hakikat dan sumbernya sama. Pancasila sebagai dasar negara memiliki pengertian yang berbeda dengan fungsi Pancasila sebagai pandangan hidup bangsa Indonesia, demikian pula berkaitan dengan kedudukan dan fungsi Pancasila yang lainnya.

Dari berbagai macam kedudukan dan fungsi Pancasila sebagai titik sentral pembahasan adalah kedudukan dan fungsi Pancasila sebagai dasar negara Republik Indonesia, hal ini sesuai dengan kausa finalis Pancasila yang dirumuskan oleh pembentuk negara pada hakikatnya adalah sebagai dasar negara Republik Indonesia. Namun hendaklah dipahami bahwa asal mula Pancasila sebagai dasar negara Republik Indonesia , adalah digali dari unsur-unsur yang berupa nilai-nilai yang terdapat pada bangsa Indonesia sendiri yang 
berupa pandangan hidup bangsa Indonesia.

Oleh karena itu dari berbagai macam kedudukan dan fungsi Pancasila sebenarnya dapat dikem-balikan pada dua macam kedudukan dan fungsi Pancasila yang pokok yaitu sebagai Dasar Negara Republik Indonesia dan sebagai Pandangan Hidup Bangsa Indonesia. (Kaelan, 2008).

Berdasarkan uraian diatas dapat disimpulkan bahwa kedudukan dan fungsi Pancasila yang pokok adalah pertama sebagai dasar negara Republik Indonesia dan yang kedua adalah sebagai pandangan hidup bangsa Indonesia ketiga sebagai ideologi bangsa dan negara. Kaelan (2008) menguraikan lebih mendalam kedudukan dan fungsi Pancasila sebagai berikut :

\section{Pancasila sebagai Pandangan Hidup Bangsa}

Manusia sebagai makhluk ciptaan Tuhan Yang Maha Esa, dalam perjuangan untuk mencapai kehidupan yang lebih sempurna, senantiasa memerlukan nilai-nilai luhur yang dijunjungnya sebagai suatu pandangan hidup. Nilai-nilai luhur adalah merupakan suatu tolok ukur kebaikan yang berkenaan dengan hal-hal yang bersifat mendasar dan abadi dalam hidup manusia, seperti cita-cita yang hendak dicapainya dalam hidup manusia.

Pandangan hidup yang terdiri atas kesatuan rangkaian nilai-nilai luhur tersebut adalah suatu wawasan yang menyeluruh terhadap kehidupan itu sendiri. Pandangan hidup berfungsi sebagai kerangka acuan baik untuk menata kehidupan diri pribadi maupun dalam interaksi antar manusia dalam masyarakat serta alam sekitarnya.

Sebagai makhluk individu dan makhluk sosial manusia tidaklah mungkin memenuhi segala kebutuhannya sendiri, oleh karena itu untuk mengembangkan potensi kemanusiaannya, ia senantiasa memerlukan orang lain. Dalam pengertian inilah maka manusia pribadi senantiasa hidup sebagai bagian dari lingkungan sosial yang lebih luas, secara berturut-turut, lingkungan keluarga, lingkungan masyarakat, lingkungan bangsa dan lingkungan negara yang merupakan lembagalembaga masyarakat utama yang diharapkan dapat menyalurkan dan mewujudkan pandangan hidupnya. Dengan demikian dalam kehidupan bersama dalam suatu negara membutuhkan suatu tekad 
kebersamaan, cita-cita yang ingin dicapainya yang bersumber pada pandangan hidupnya tersebut.

Dalam pengertian inilah maka proses perumusan pandangan hidup masyarakat dituangkan dan dilembagakan menjadi pandangan hidup bangsa dan selanjutnya pandangan hidup bangsa dituangkan dan dilembagakan menjadi pandangan hidup negara. Pandangan hidup bangsa dapat disebut sebagai ideologi bangsa (nasional), dan pandangan hidup negara dapat disebut, sebagai ideologi negara.

Dalam proses penjabaran dalam kehidupan modern antara pandangan hidup masyarakat dengan pandangan hidup bangsa memiliki hubungan yang bersifat timbal balik. Pandangan hidup bangsa diproyeksikan kembali kepada pandangan hidup masyarakat serta tercermin dalam sikap hidup pribadi warganya. Dengan demikian dalam negara Pancasila pandangan hidup masyarakat tercermin dalam kehidupan negara yaitu Pemerintah terikat oleh kewajiban konstitusional, yaitu kewajiban Pemerintah dan lain-lain penyelenggara negara untuk memelihara budi pekerti kemanusiaan yang luhur dan memegang teguh cita-cita moral rakyat yang luhur, Darmodihardjo (dalam Kaelan 2008). Skema hubungan tersebut adalah sebagai berikut.

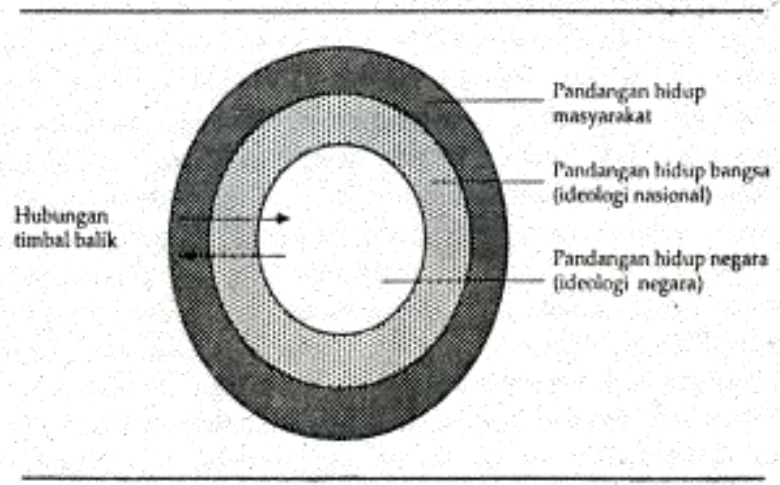

Transformasi pandangan hidup masyarakat menjadi pandangan hidup bangsa dan akhirnya menjadi dasar negara juga terjadi pada pandangan hidup Pancasila. Pancasila sebelum dirumuskan menjadi dasar negara serta ideologi negara, nilai-nilainya telah terdapat pada bangsa Indonesia dalam adat-istiadat, dalam budaya serta dalam agama-agama sebagai pandangan hidup masyarakat Indonesia. Pandangan yang ada pada masyarakat Indonesia tersebut kemudian menjelma menjadi pandangan hidup bangsa yang telah terintis sejak zaman Sriwijaya, Majapahit kemudian Sumpah Pemuda 1928. Kemudian diangkat dan dirumuskan oleh para pendiri negara dalam sidang-sidang BPUPKI, 
Panitia "Sembilan", serta sidang PPKI kemudian ditentukan dan disepakati sebagai dasar negara republik Indonesia, dan dalam pengertian inilah maka Pancasila sebagai Pandangan Hidup negara dan sekaligus sebagai Ideologi Negara.

Bangsa Indoensia dalam hidup bernegara telah memiliki suatu pandangan hidup bersama yang bersumber pada akar budayanya dan nilai-nilai religiusnya. Dengan pandangan hidup yang mantap maka bangsa Indonesia akan mengetahui ke arah mana tujuan yang ingin dicapainya. Dengan suatu pandangan hidup yang diyakininya bangsa Indonesia akan mampu memandang dan memecahkan segala persoalan yang dihadapinya secara tepat sehingga tidak terombang-ambing .dalam menghadapi persoalan tersebut. Dengan suatu pandangan hidup yang jelas maka bangsa Indonesia akan memiliki pegangan dan pedoman bagaimana mengenai dan memecahkan berbagai masalah politik, sosial budaya. ekonomi, hukum, hankam dan persoalan lainnya dalam gerak masyarakat yang semakin maju.

Pancasila sebagai pandangan hidup bangsa tersebut terkandung di dalamnya konsepsi dasar mengenai kehidupan yang dicita-citakan, terkandung dasar pikiran terdalam dan gagasan mengenai wujud kehidupan yang dianggap baik. Oleh karena Pancasila sebagai pandangan hidup bangsa merupakan suatu kristalisasi dari nilai-nilai yang hidup dalam masyarakat Indonesia, maka pandangan hidup tersebut dijunjung tinggi oleh warganya karena pandangan hidup Pancasila berakar pada budaya dan pandangan hidup masyarakat. Dengan demikian pandangan hidup Pancasila bagi bangsa Indonesia yang Bhinneka Tunggal Ika tersebut harus merupakan asas pemersatu bangsa sehingga tidak boleh mematikan keanekaragaman.

Sebagai inti sari dari nilai budaya masyarakat Indonesia, maka Pancasila merupakan cita-cita moral bangsa yang memberikan pedoman dan kekuatan rohaniah bagi bangsa untuk berperilaku luhur dalam kehidupan sehari dalam bermasyarakat, berbangsa dan bernegara.

\section{Pancasila sebagai Dasar Negara}

\section{Republik Indonesia}

Pancasila dalam kedudukannya ini sering disebut sebagai Dasar Filsafat atau Dasar Falsafah Negara (Philosofische 
Gronslag) dari negara, ideologi negara atau (Staatsidee). Dalam pengertian ini Pancasila merupakan suatu dasar nilai serta norma untuk mengatur pemerintahan negara atau dengan lain perkataan Pancasila merupakan suatu dasar untuk mengatur penyelenggaraan negara. Konsekuensinya seluruh pelaksanaan dan penye-lenggaraan negara terutama segala peraturan perundangundangan termasuk proses reformasi dalam segala bidang dewasa ini, dijabarkan dan diderivasikan dari nilai-nilai Pancasila. Maka Pancasila merupakan Sumber dari segala sumber hukum, Pancasila merupakan sumber kaidah hukum negara yang secara konstitusional mengatur negara Republik Indonesia beserta seluruh unsur-unsurnya yaitu rakyat, wilayah, serta pemerintahan negara.

Sebagai dasar negara, Pancasila merupakan suatu asas kerokhanian yang meliputi suasana kebatinan atau cita-cita hukum, sehingga merupakan suatu sumber nilai, norma serta kaidah, baik moral maupun hukum negara, dan menguasai hukum dasar baik yang tertulis atau UndangUndang Dasar maupun yang tidak tertulis atau konvensi. Dalam kedudukannya sebagai dasar negara, Pancasila mempunyai kekuatan mengikat secara hukum.

Sebagai sumber dari segala sumber hukum atau sebagai sumber tertib hukum Indonesia maka Pancasila tercantum dalam ketentuan tertinggi yaitu Pembukaan UUD 1945, kemudian dijelmakan atau dijabarkan lebih lanjut dalam pokok-pokok pikiran, yang meliputi suasana kebatinan dari UUD 1945, yang pada akhirnya dikongkritisasikan atau dijabarkan dalam pasal-pasal UUD 1945, serta hukum positif lainnya. Kedudukan Pancasila sebagai dasar negara tersebut dapat dirinci sebagai berikut:

a) Pancasila sebagai dasar negara adalah merupakan sumber dari segala sumber hukum (sumber tertib hukum) Indonesia. Dengan demikian Pancasila merupakan asas kerokhanian tertib hukum Indonesia yang dalam Pembukaan UUD 1945 dijelmakan lebih lanjut ke dalam empat pokok pikiran,

b) Meliputi suasana kebatinan (Geistlichenhintergrund) dari UndangUndang Dasar 1945.

c) Mewujudkan cita-cita hukum bagi hukum dasar negara (baik hukum dasar tertulis maupun tidak tertulis 
d) Mengandung norma yang mengharuskan Undang-Undang Dasar mengandung isi yang mewajibkan pemerintah dan lainlain penyelenggara negara (termasuk para penyelenggara partai dan golongan fungsional) memegang teguh cita-cita moral rakyat yang luhur. Hal ini sebagaimana tercantum dalam pokok pikiran keempat yang bunyinya sebagai berikut: ".... Negara berdasarkan atas Ketuhanan Yang Maha Esa, menurut dasar kemanusiaan yang adil dan beradab $"$.

e) Merupakan sumber semangat bagi Udang-undang Dasar 1945, bagi penyelenggara negara, para pelaksana pemerintahan (juga para penyelenggara partai dan golongan fungsional). Hal ini dapat dipahami karena semangat adalah penting bagi pelaksanaan dan penyelenggaraan negara, karena masyarakat dan negara Indonesia senantiasa tumbuh dan berkembang seiring dengan perkembangan zaman dan dinamika masyarakat. Dengan semangat yang bersumber pada asas kerokhanian negara sebagai pandangan hidup bangsa, maka dinamika masyarakat dan negara akan tetap diliputi dan diarahkan asas kerokhanian negara.

Dasar formal kedudukan Pancasila sebagai dasar negara Republik Indonesia tersimpul dalam Pembukaan UUD 1945 alinea IV yang bunyinya sebagai berikut:" ......maka disusunlah kemerdekaan kebangsaan Indonesia itu dalam suatu Undang-Undang Dasar negara Indonesia, yang terbentuk dalam suatu susunan negara Republik Indonesia yang berkedaulatan rakyat, dengan berdasar kepada Ketuhanan Yang Maha Esa, kemanusiaan yang adil dan beradab, persatuan Indonesia, kerakyatan yang dipimpin oleh hik-mat kebijaksanaan dalam permusyawaratan/perwakilan, serta dengan mewujudkan suatu keadilan sosial bagi seluruh rakyat Indonesia ".

Pengertian kata ".... Dengan berdasar kepada ..." hal ini secara yuridis memiliki makna sebagai dasar negara. Walaupun dalam kalimat terakhir Pembukaan UUD 1945 tidak tercantum kata 'Pancasila' secara eks-plisit namun anak kalimat "... dengan berdasar kepada ...." Ini memiliki makna dasar negara adalah Pancasila. Hal ini didasarkan atas interpretasi historis sebagaimana ditentukan oleh BPUPKI 
bahwa dasar negara Indonesia itu disebut dengan istilah Pancasila.

Sebagaimana telah ditentukan oleh pembentukan negara bahwa tujuan utama dirumuskannnya Pancasila adalah sebagai dasar negara Republik Indonesia. Oleh karena itu fungsi pokok Pancasila adalah sebagai dasar negara Republik hidonesia. Hal ini sesuai dengan dasar yuridis sebagaimana tercantum dalam Pembukaan UUD 1945, ketetapan No XX/MPRS/1966. (Jo Ketetapan MPR No.V/MPR/1973 dan Ketetapan No. IX/MPR/1978). Di-jelaskan bahwa Pancasila sebagai sumber dari segala sumber hukum atau sumber tertib hukum Indonesia yang pada hakikatnya adalah merupakan suatu pandangan hidup, kesadaran dan cita-cita hukum serta cita-cita moral yang meliputi suasana kebatinan serta watak dari bangsa Indonesia. Selanjutnya dikatakannya bahwa cita-cita tersebut adalah meliputi cita-cita mengenai kemerdekaan individu, kemerdekaan bangsa, perikemanusiaan, keadilan sosial, perdamaian nasional dan mondial, cita-cita politik mengenai sifat, bentuk dan tujuan negara, cita-cita moral mengenai kehidupan kemasyarakatan dan keagamaan sebagai pengejawantahan dari budi nurani manusia.

Dalam proses reformasi dewasa ini MPR melalui Sidang Istimewa tahun 1998, mengembalikan kedudukan Pancasila sebagai dasar negara Republik Indonesia yang tertuang dalam Tap. No. XVIII/MPR/1998. Oleh karena itu segala agenda dalam proses reformasi, yang meliputi berbagai bidang selain mendasarkan pada kenyataan aspirasi rakyat (Sila IV) juga harus mendasarkan pada nilainilai yang terkandung dalam Pancasila. Reformasi tidak mungkin menyimpang dari nilai ketuhanan, kemanusiaan, persatuan, kerakyatan serta keadilan, bahkan harus bersumber kepadanya.

\section{Pancasila sebagai ideologi Bangsa dan}

\section{Negara Indonesia}

Sebagai suatu ideologi bangsa dan negara Indonesia maka Pancasila pada hakikatnya bukan hanya merupakan suatu hasil perenungan atau pemikiran seseorang atau kelompok orang sebagaimana ideologiideologi lain didunia, namun Pancasila diangkat dari nilai-nilai adat-istiadat, nilainilai kebudayaan serta nilai religius yang terdapat dalam pandangan hidup masyarakat 
hidonesia sebelum membentuk negara, dengan lain perkataan unsur-unsur yang merupakan materi (bahan) Pancasila tidak lain diangkat dari pandangan hidup masyarakat hidonesia sendiri, sehingga bangsa ini merupakan kausa materialis (asal bahan) Pancasila .

\section{Unsur-unsur Pancasila tersebut} kemudian diangkat dan dirumuskan oleh para pendiri negara, sehingga Pancasila berkedudukan sebagai dasar negara dan ideologi bangsa dan negara Indonesia. Dengan demikian Pancasila sebagai ideologi bangsa dan negara hidonesia berakar pada pandangan hidup dan budaya bangsa, dan bukannya mengangkat atau mengambil ideologi dari bangsa lain. Selain itu Pancasila juga bukan hanya merupakan ideide atau perenungan dari seseorang saja, yang hanya memperjuangkan suatu kelompok atau golongan tertentu, melainkan Pancasila berasal dari nilai-nilai yang dimiliki oleh bangsa sehingga Pancasila pada hakikatnya untuk seluruh lapisan serta unsur-unsur bangsa secara komperhensif. Oleh karena ciri khas Pancasila itu maka memiliki kesesuaian dengan bangsa Indonesia.
4. Pancasila sebagai Ideologi yang

\section{Reformatif, Dinamis dan Terbuka}

Pancasila sebagai suatu ideologi tidak bersifat kaku dan tertutup, namun bersifat reformatif, dinamis dan terbuka. Hal ini dimaksudkan bahwa ideologi Pancasila adalah bersifat aktual, dinamis, antisipatif dan senantiasa mampu menyesuaikan dengan perkembangan zaman, ilmu pengetahuan dan teknologi serta dinamika perkembangan aspirasi masyarakat. Keterbukaan ideologi Pancasila bukan berarti mengubah nilai-nilai dasar yang terkandung di dalamnya, namun mengeksplisitkan wawasannya secara lebih kongkrit, sehingga memiliki kemampuan yang reformatif untuk memecahkan masalah-masalah aktual yang senantiasa berkembang seiring dengan aspirasi rakyat, perkembangan iptek serta zaman.

Dalam ideologi terbuka terdapat cita-cita dan nilai-nilai yang mendasar yang bersifat tetap dan tidak berubah sehingga tidak langsung bersifat operasional, oleh karena itu setiap kali harus dieksplisitkan. Eksplisitasi dilakukan dengan menghadapkannya pada berbagai masalah yang selalu silih berganti melalui refleksi 
yang rasional sehingga terungkap makna operasionalnya. Dengan demikian penjabaran ideologi dilaksanakan dengan inter-pretasi yang kritis dan rasional, Soeryanto (dalam Kaelan 2008). Sebagai suatu contoh keterbukaan ideologi Pancasila antara lain dalam kaitannya dengan kebebasan berserikat berkumpul sekarang terdapat 48 partai politik, dalam kaitan dengan ekonomi (misalnya ekonomi kerakyatan), demikian pula dalam kaitannya dengan pendidikan, hukum, kebudayaan, iptek, hankam dan bidang lainnya.

Berdasarkan pengertian tentang ideologi terbuka tersebut nilai-nilai yang terkandung dalam ideologi Pancasila sebagai ideologi terbuka adalah sebagai berikut:

Nilai Dasar, yaitu hakikat kelima sila Pancasila yaitu Ketuhanan, kemanusiaan, persatuan, kerakyatan dan keadilan. Nilai dasar tersebut adalah merupakan esensi dari sila-sila Pancasila yang bersifat universal, sehingga dalam nilai dasar tersebut terkandung cita-cita, tujuan serta nilai-nilai yang baik dan benar. Nilai dasar ideologi tersebut tertuang dalam Pembukaan UUD 1945, sehingga oleh karena Pembukaan memuat nilai-nilai dasar ideologi Pancasila maka Pembukaan UUD 1945 merupakan suatu norma dasar yang merupakan tertib hukum tertinggi, sebagai sumber hukum positif sehingga dalam negara memiliki kedudukan sebagai 'Staatsfundamentalnorm' atau pokok kaidah negara yang fundamental. Sebagai ideologi terbuka nilai dasar inilah yang bersifat tetap dan terlekat pada kelangsungan hidup negara, sehingga mengubah Pembukaan UUD 1945 yang memuat nilai dasar ideologi Pancasila tersebut sama halnya dengan pembubaran negara. Adapun nilai dasar tersebut kemudian dijabarkan dalam pasal-pasal UUD 1945 yang didalamnya terkandung lembaga-lembaga penyelenggaraan negara, hubungan antara lembaga penyelenggara negara beserta rugas dan wewenangnya.

Nilai Instrumental, yang merupakan arahan, kebijakan, strategi, sasaran serta lembaga pelaksanaannya. Nilai instrumental ini merupakan eksplisitasi, penjabaran lebih lanjut dari nilai-nilai dasar ideologi Pancasila. Misalnya Garis-Garis Besar Haluan Negara yang lima tahun senantiasa disesuaikan dengan perkembangan zaman serta aspirasi masyarakat, undang-undang, departemen-departemen sebagai lembaga 
pelaksanaan dan lain sebagainya. Pada aspek ini senantiasa, dapat dilakukan perubahan (reformatif).

Nilai Praksis, yaitu merupakan realisasi nilai-nilai instramental dalara suatu realisasi pengamalan yang bersifat nyata, dalam kehidupan se-hari-hari dalam berniasyarakat, berbangsa dan bernegara, BP-7 Pusat (dalam Kaelan 2008). Dalam realisasi praksis inilah maka penjabaran nilai-nilai Pancasila senantisa berkembang dan selalu dapat dilakukan perubahan dan perbaikan (reformasi) sesuai dengan perkembangan zaman ilmu pengetahuan dan teknologi serat aspirasi rnasyarakat.

Suatu ideologi selain memiliki aspek-aspek yang bersifat ideal yang berupa cita-cita, pemikiran-pemikiran serta nilainilai yang dianggap baik, juga harus memiliki norma yang jelas karena ideologi harus mampu direalisasikan dalam kehidupan praksis yang merupakan suatu aktualisasi secara kongkret. Oleh karena itu Pancasila sebagai ideologi terbuka secara struktural memiliki tiga dimensi yaitu:

(1) Dimensi Idealistis, yaitu nilai-nilai dasar yang terkandung dalam Pancasila yang bersifat sistematis, rasional dan menyeluruh, yaitu hakikat nilai-nilai yang terkandung dalam sila-sila Pancasila yaitu Ketuhanan, kemanusiaan, persatuan, kerakyatan dan keadilan. Hakikat nilai-nilai Pancasila tersebut bersumber pada filsafat Pancasila (nilai-nilai filosofis yang terkandung dalam Pancasila). Karena setiap ideologi bersumber pada suatu nilai-nilai filosofis atau sistem filsafat, Soeryanto (dalam Kaelan 2008). Kadar serta idealisme yang terkandung dalam Pancasila mampu memberikan harapan, optimisme serta mampu menggugah motivasi para pendukungnya untuk berupaya mewujudkan apa yang dicita-citakan (Koento Wibisono, 1989).

(2) Dimensi Normatif, yaitu nilai-nilai yang terkandung dalam Pancasila perlu dijabarkan dalam suatu sistem norma, sebagaimana terkandung dalam norma-norma kenegaraan. Dalam pengertian ini Pancasila terkandung dalam Pembukaan UUD 1945 yang merupakan norma tertib hukum tertinggi dalam negara Indonesia serta merupakan Staatsfundamentalnorm (Pokok Kaidah Negara yang Fundamental). Dalam pengertian ini ideologi Pancasila agar 
mampu dijabarkan ke dalam langkah operasional, maka perlu memiliki norma yang jelas, Soeryanto (dalam Kaelan2008).

(3) Dimensi Realistis, yaitu suatu ideologi harus mampu mencer-minkan realitas yang hidup dan berkembang dalam masyarakat. Oleh karena itu Pancasila selain memiliki dimensi nilai-nilai ideal serta normatif maka Pancasila harus mampu dijabarkan dalam kehidupan masyarakat secara nyata (konkrit) baik dalam kehidupan sehari-hari maupun dalam penyelenggaraan negara. Dengan demikian Pancasila sebagai ideologi terbuka tidak bersifat 'utopis' yang hanya berisi ideide yang bersifat mengawang, melainkan suatu ideologi yang bersifat 'realistis' artinya mampu dijabarkan dalam segala aspek kehidupan nyata.

Berdasarkan dimensi yang dimiliki oleh Pancasila sebaga ideologi terbuka, maka sifat ideologi Pancasila tidak bersifat 'utopis' yaitu hanya merupakan sistem ideide belaka yang jauh dari kehidupan seharihari secara nyata. Demikian pula ideologi Pancasila bukanlah merupakan suatu 'doktrin' belaka yang bersifat tertutup yang merupakan norma-norma yang beku. melainkan di samping memiliki idealisme,
Pancasila juga bersifat nyata dan reformatif yang mampu melakukan perubahan. Akhirnya Pancasila juga bukan merupakan suatu ideologi yang 'pragmatis' yang hanya menekankan segi praktis-praktis belaka tanpa adanya aspek idealisme. Maka ideologi Pancasila yang bersifat terbuka pada hakikatnya, nilai-nilai dasar (hakikat sila-sila Pancasila) yang bersifat universal dan tetap, adapun penjabaran dan realisasinya senantiasan dieksplisitkan secara dinamis reformatif yang senantiasa mampu melakukan perubahan sesuai dengan dinamika aspirasi masyarakat. Hal inilah yang merupakan aspek penting dalam negara sebab suatu negara harus memiliki landasan nilai, dasar nilai serta asas kerokhanian yang jelas yang memberikan arahan, motivasi, serta visi bagi bangsa dan negara dalam menghadapi perkembangan dunia yang semakin tidak menentu ini. Proses reformasi yang dewasa ini agar tidak terjebak pada suatu ajang perebutan kekuasaan oleh kelompok-kelompok yang merupakan kekuatan sosial politik negara maka, sudah seharusnya melakukan revitalisasi ideologi negara yang merupakan dasar hidup bersama. 
Implementasi nilai-nilai Pancasila itu perlu dilakukan dengan memperkuat kembali fundamen etis dan karakter bangsa berdasarkan falsafah dan pandangan bangsa Indonesia. Yudi Latif, (kompas 28/3/2011), menguraikan pentingnya kembali ke Pancasila, dalam mengatasi krisis kebangsaan.

"Akibat keteledoran, ketidaktaatan, dan penyelewengan atas nilai-nilai Pancasila, terutama oleh penyelenggara negara, Pancasila sebagai bintang pemimpin itu pun redup tertutup kabut; menimbulkan kegelapan dalam rumah kebangsaan. Lantas anak anak negeri berusaha mencari kunci jawaban atas persoalan negerinya di luar 'rumah'. seseorang bertanya, ' apa gerangan yang kalian cari?' anak anak negeri itu pun menjawab, 'kunci rumah'. Memangnya dimana hilangnya kunci itu?, 'Didalam rumah sendiri'. 'Mengapa kalian cari di luar rumahmu? "Karena rumah kami gelap “.

\section{BAB III}

\section{METODE PENELITIAN}

\section{A. Desain Penelitian}

Jenis penelitian yang kami lakukan adalah tergolong penelitian deskriptif kualitatif. karakter khusus penelitian kualitatif berupaya mengungkap keunikan individu, kelompok, masyarakat dan organisasi tertentu dalam kehidupan seharihari yang diharapkan dapat menghasilkan suatu deskripsi tentang ucapan, tulisan, perilaku yang diamati dalam seting tertentu (Basrowi, 2002). Menggali informasi tentang persepsi mahasiswa berkaitan dengan tema Pancasila sebagai identitas nasional.

\section{B. Variabel Penelitian dan Definisi Operasional}

Variabel penelitian ini adalah persepsi mahasiswa dan Pancasila sebagai identitas nasional.

Yang dimaksud persepsi mahasiswa adalah pandangan, penilaian dan anggapan 
mahasiswa IKIP PGRI Madiun tentang Pancasila sebagai Identias nasional

Yang dimaksud Pancasila sebagai nasional identitas adalah karakter, identitas, kepribadian yang dimiliki oleh bangsa Indonesia yang menjadi ciri khas untuk membedakan dengan bangsa lain.

\section{Subyek penelitian, teknik penentuan subyek}

Subyek penelitian ini adalah mereka yang masuk kategori mahasiswa IKIP PGRI Madiun yang masih aktif baik laki-laki maupun perempuan yakni semester 2 dan semester 4. Berdasarkan paradigma penelitian kualitatif, diambil secara proporsional dengan mempertimbangkan jenis kelamin, asal usul program studi, latar belakang aktifitas di kampus.

Dua angkatan (semester 2 dan 4) di semua Program Studi di IKIP PGRI madiun diambil secara proporsional 2 mahasiwa (laki-laki dan perempuan). Dengan demikian jumlah informan di setiap prodi diambil 4 mahasiswa. Di IKIP PGRI Madiun ada 11 Prodi yang terpilih, jadi total informan yang dipilih secara proporsional adalah sejumlah 44 mahasiswa.

\section{Lokasi Penelitian}

Lokasi penelitian berada di lingkungan IKIP PGRI Madiun.

\section{E. Teknik pengumpulan Data}

Data yang dibutuhkan adalah dari sumber primer dan sekunder. Data primer berupa keterangan atau fakta dilokasi penelitian diperoleh dari informan, dan peristiwa atau aktifitas. Data sekunder berupa dokumen dan arsip tentang objek penelitian, baik berupa dokumen kurikulum, buku-buku sumber pembelajaran maupun data lain yang terkait seperti majalah dan surat kabar. Pengumpulan data primer dilakukan dengan teknik wawancara mendalam dan observasi langsung. Wawancara dilakukan melalui dua pendekatan yakni tak terstruktur dan wawancara terstruktur. (Dedy Mulyana,2002). Wawancara dilakukan khusus dengan mereka yang masuk kategori mahasiswa yang terpilih dalam penelitian ini. 
Selain itu pengumpulan data juga dilakukan melalui focus group discussion (FGD). FGD merupakan teknik penggalian data yang dilakukan dengan menggunakan pertanyaan secara terfokus. FGD tidak dimaksudkan untuk memperoleh kesepakatan / konsensus dari para peserta yang hadir tetapi untuk memperoleh informasi yang lebih mendalam baik berupa pengalaman, opini, sikap, harapan dari peserta yang diharapkan mewakili persepsi mahasiswa. Adapun yang terpilih untuk terlibat dalam FGD ini adalah 44 mahasiswa yang terpilih sebagai informan yang akan dibagi menjadi dua gelombang FGD.

\section{F. Teknik analisis Data.}

Analisis data dilakukan dengan metode analisis data kualitatif. Analisis data ditujukan pada data data yang sifatnya kualitas dan sifat yang nyata diterapkan di lokasi penelitian. Ada dua cara yang digunakan dalam penelitian ini, yaitu analisis isi dan analisis interaktif. untuk data dokumen dan arsip digunakan analisis isi sedangkan untuk data hasil wawancara, FGD, dan observasi digunakan analisis interaktif, seperti dikemukakan Milles dan Huberman (1996). Data yang diperoleh kemudian didokumentasikan dan dianalisis sehingga menghasilkan rekomendasi yang sesuai dengan tujuan penelitian. Selengkapnya dapat digambarkan dalam bagan berikut ini.

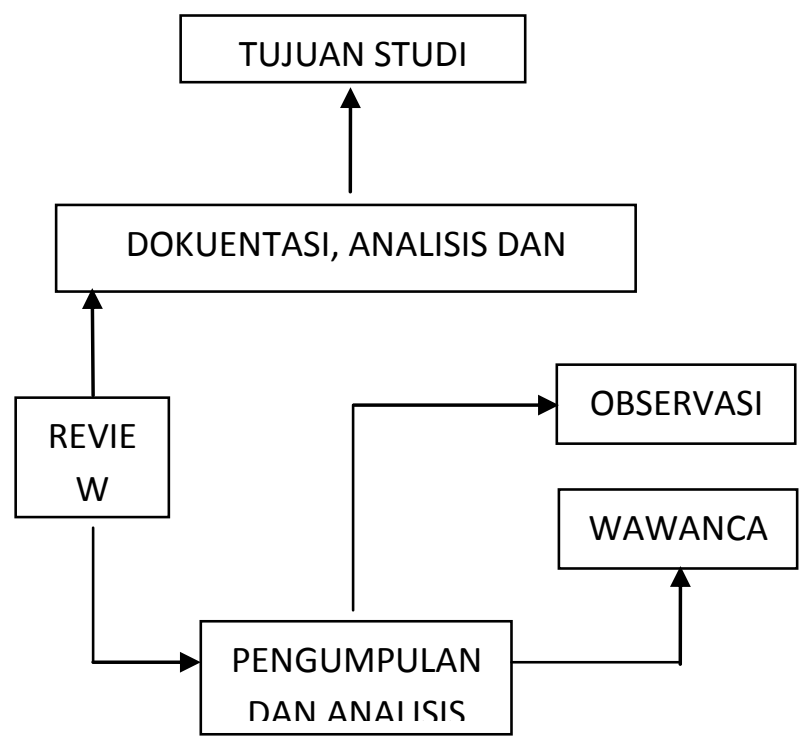

Bagan 2 : Komponen dalam analisa data 


\section{BAB IV}

\section{HASIL PENELITIAN DAN PEMBAHASAN}

\section{A. Persepsi Mahasiswa Tentang} Pancasila.

Mayoritas mahasiswa dapat menyebutkan Pancasila secara baik dan berurutan. Hafalnya sila-sila dalam Pancasila tidak lepas dari kebiasaan sejak siswa sekolah dasar selalu dituntut hafal Pancasila. Apalagi setiap hari senin atau peringatan hari-hari besar nasional, selalu membacakan Pancasila dalam rangkaian upacara. Di IKIP PGRI Madiun setiap kali upacara pada peringatan hari-hari besar juga menggelar upacara. Hal ini lah yang menjadi salah satu alasan rasional kenapa mereka yang menjadi informan hampir tidak ada yang menyebut salah Pancasila. Ada sebagian kecil yang kurang tepat menyebutkan hanya karena kurang konsentrasi saja ketika diwawancarai. Namun pada akhirnya semua dapat mengucapkan sila-sila dalam Pancasila dengan benar. Secara umum, istilah Pancasila bukan kata yang asing bagi mahasiswa karena mereka telah mengenal sejak masa kanak-kanak. Dan persepsi informan tentang Pancasila juga cukup memadahi untuk meletakkan fungsi dan kedudukan Pancasila dalam konteks wawasan berbangsa dan bernegara.

Menyinggung pengertian Pancasila sebagian besar memahami Pancasila sebagai alat untuk menyatukan bangsa Indonesia. Pancasila dibayangkan sebagai perekat bangsa Indonesia yang sangat majemuk. Baik dari sisi etnis, tradisi, budaya, adatistiadat, bahasa daerah dan lain-lain. Mayoritas mampu mendeskripsikan bahwa Pancasila memegang peranan penting untuk eksistensi Negara Indonesia. Tanpa adanya Pancasila, Negara Indonesia tidak akan memiliki fondasi yang kuat. Disisi lain ada yang memahami Pancasila sila demi sila sesuai persepsi yang mereka pahami, tanpa bisa memahami fungsi dan peran Pancasila lebih jauh. Namun mayoritas dapat memahami Pancasila dengan cukup baik. Sebagian mahasiswa ada yang membayangkan Pancasila sebagai simbul negara. Persepsi ini tidak lepas dari keberadaan lambang garuda Pancasila yang secara filisofis juga merefleksikan sila-sila dalam Pancasila. Dengan kata lain, 
pemahaman tentang pengertian Pancasila di kalangan mahasiswa IKIP PGRI madiun relatif baik. Memang ada variasi pada level konsep dalam memahami Pancasila, namun secara prinsipal dapat dikatakan bahwa mahasiswa telah mengerti Pancasila.

Mayoritas mahasiswa bisa menyebutkan Pancasila berikut dengan fungsinya, antara lain sebagai dasar Negara, landasan ideology, sumber dari segala sumber hukum, pandangan hidup bangsa, kepribadian bangsa, perjanjian luhur. Namun tidak mampu menjelaskan lebih lanjut apa maksud dari fungsi-fungsi tersebut. Tetapi mayoritas dari mereka dapat menyebut fungsi-fungsi tersebut. Hal ini menunjukkan bahwa wawasan tentang pancasila khususnya terkait fungsinya telah dipahami dengan baik oleh sebagian besar mahasiswa. Meskipun mayoritas tidak mampu menjelaskan lebih jauh tentang apa maksud dari fungsi-fungsi tersebut. Penjelasan akademis mereka tentang fungsifungsi itu masih sangat dangkal. Tetapi secara substansial pemahaman mereka tentang fungsi-fungsi tersebut secara umum cukup memadahi. Memang tidak ada yang mampu menyebutkan secara persis sesuai definisi yang tersedia, namun secara fundamental mereka dapat dikatakan telah memahami fungsi-fungsi tersebut.

Pancasila sebagai dasar negara adalah sebagai fundamen yang kuat dan kokoh dimana diatasnya didirikan negara Indonesia yang kekal abadi. Diatas dasar ini kita dapat menyatukan segenap unsur-unsur dari bangsa Indonesia. Berdasarkan hasil penelitian menunjukkan bahwa sebagian besar mahasiswa dapat memahami Pancasila sebagai dasar negara. Dapat diartikan bahwa mahasiswa mampu memberikan makna, untuk mendirikan negara Indonesia yang kuat dan kokoh perlu adanya landasan, diatas landasan tersebut dapat menampung keberagaman elemen-elemen bangsa yang majemuk baik suku, budaya, ras, agama sebagai pengikat atau untuk mempersatukannya.

Pancasila sebagai dasar Negara sebagian besar mahasiswa memahaminya sebagai dasar penyelenggaraan pemerintahan. Sebagian yang lain menjelaskan bahwa Pancasila sebagai dasar Negara merupakan rujukan hukum yang harus dipatuhi oleh para penyelenggara Negara. Ada yang memahaminya sebagai 
fondasi bagi eksistensi NKRI. Prinsipnya kata dasar Negara dapat dijelaskan oleh para mahasiswa sesuai dengan persepsinya masing-masing, namun dalam koridor yang bisa dipahami secara akademis. Prinsipnya Pancasila sebagai dasar Negara dapat dipersepsikan dengan baik oleh sebagian besar informan. Memang ada sebagian kecil mahasiswa yang tidak menjawab tentang pengertian Pancasila sebagai dasar negara, namun sebagian besar menjawab dengan pemahaman yang cukup baik. Artinya, dapat disimpulkan bahwa pemahaman Pancasila sebagai dasar negara dapat dipamahami cukup baik di kalangan mahasiswa IKIP PGRI Madiun.

Sebagai pandangan hidup bangsa, Pancasila dipahami oleh mahasiswa yang jadi informan dalam penelitian ini secara beragam. Ada yang mendeskripsikan bahwa pandangan hidup bangsa itu merupakan pedoman bagi masyarakat dalam berinteraksi dan berkomunikasi antara masyarakat. Sebagian yang lain menyebut sebagai panduan hidup warga Negara dalam melakukan aktifitas apapun, ada yang menyebut sebagai pedoman berperilaku. Secara substansial ada benang merah yang sama bahwa pada prinsipnya Pancasila sebagai pandangan hidup bangsa dapat dijelaskan oleh mayoritas informan dengan baik meski beragam sudut pandangnya namun memiliki banyak kesamaan secara esensial. Ada sebagian kecil informan yang tidak menjawab, namun mayoritas menjawab dengan bahasa dan kalimat mereka sendiri, yang hakekatnya sudah mendekati pengertian pandangan hidup bangsa. Pemahaman tentang Pancasila yang sangat beragam di kalangan mahasiswa tidak mengurangi persepsi dan pemahaman mereka secara esensial bahwa Pancasila sebagai pandangan hidup bangsa memiliki pengaruh dan peran yang signifikan bagi bangsa Indonesia sekaligus mempunyai fungsi yang vital untuk pedoman hidup bermasyarakat, berbangsa dan bernegara.

Pancasila sebagai pandangan hidup bangsa Indonesia adalah tuntunan dinamis atau bintang pimpinan kearah mana bangsa dan negara Indonesia harus digerakkan. Berdasar hasil penelitian menunjukkan bahwa, mayoritas mahasiswa mengetahui arti Pancasila sebagai pandangan hidup bangsa. Dapat diartikan bahwa mahasiswa mampu memahami Pancasila sebagai 
Pandangan hidup bangsa Indonesia bahwa untuk mencapai cita-cita bangsa Indonesia yang adil dan sejahtera harus berdasarkan visi atau arah yang telah digariskan pada nilai-nilai yang terdapat dalam Pancasila. Pancasila sebagai pandangan hidup bangsa Indonesia merupakan bintang penuntun (leibster), pemandu arah perjalanan bangsa Indonesia dalam mencapai tujuan nasionalnya, sedangkan Pancasila sebagai dasar negara merupakan pondasi yang kokoh diatasnya didirikan Negara Kesatuan Republik Indonesia.

$\begin{array}{rrr} & \text { Pancasila sebagai } & \text { kepribadian } \\ \text { bangsa, sebagian besar mahasiswa }\end{array}$ menyebutnya sebagai karakteristik atau ciriciri yang membedakan dengan bangsa lain. Namun ada yang tidak bisa menjelaskan maksud dari Pancasila sebagai kepribadian bangsa. Rata-rata masih rancu membedakan Pancasila sebagai pandangan hidup bangsa dengan fungsinya sebagai kepribadian bangsa. Intinya Pancasila dipersepsikan sebagai identitas yang digali dari nilai-nilai yang asli bangsa Indonesia sendiri. Dan identitas nasional banyak dipahami dalam koridor Pancasila sebagai kepribadian bangsa. Dengan kata lain, mayoritas informan dalam penelitian ini dapat disimpulkan mampu memahami Pancasila sebagai kepribadian bangsa dengan baik. Memang Pancasila sebagai identitas nasional seringkali ditafsirkan hampir sama dengan pemahaman Pancasila sebagai kepribadian bangsa.

Pancasila sebagai perjanjian luhur banyak yang mengetahui dengan baik sebagai sebuah dokumen penting yang merupakan kesepakatan para pendiri bangsa ini. Namun sebagian yang lain ada yang tidak menjawab. Pengertian perjanjian luhur tentu dipersepsikan beragam, tetapi memiliki jalur pengertian yang relative sama. Yakni Pancasila lahir dari sebuah komitmen yang mulia dari para founding fathers bangsa ini. Para pemimpin kita saat itu sudah sepakat bahwa Pancasila merupakan nilai-nilai dasar yang menjadi pijakan bagi berdirinya negara Indonesia. Dan komitmen itu dituangkan dalam nilainilai yang terkandung dalam Pancasila. Ada perdebatan soal Pancasila sebagai perjanjian luhur, yakni mengenai ide siapa yang lebih dominan tentang Pancasila yang kita pake. Apakah dominasi Soekarno, Hatta, Moh 
Yamin, Soepomo atau tokoh lain. Tetapi mereka ada persepsi yang sama bahwa teks Pancasila yang kita gunakan saat ini adalah sebagaimana yang tercantum dalam Pembukaan UUD 1945, bukan berasal dari Piagam Jakarta atau yang lain.

Negara Indonesia adalah negara yang berdasarkan atas hukum sehingga segala aspek ketatanegaraan harus berdasarkan hukum positif. Segala bentuk peraturan yang akan diberlakukan (menjadi hukum positif) terlebih dahulu harus disesuaikan dengan nilai-nilai yang terkandung dalam Pancasila. Karena lima dasar negara itulah yang akan menjadi barometer dalam membentuk aturan yang bersifat hierarkis. Aturan yang lebih rendah tidak boleh bertentangan dengan peraturan yang lebih tinggi.

Pancasila sebagai sumber dari segala sumber hukum dapat dipahami dengan baik oleh sebagian besar mahasiswa karena pengertian ini mudah untuk dilogika sesuai dengan common sense mahasiswa bahwa tidak ada rujukan hukum tertinggi selain Pancasila. Namun pengertian yang mereka ucapkan relative dapat diterima secara logis meski argumentasinya sangat variatif. Pancasila harus menjadi landasan hukum bagi semua produk hukum yang ada di Indonesia. Substansi jawaban mayoritas informan adalah semua produk hukum yang ada tidak boleh berlawanan dengan nilainilai Pancasila. Hampir semua mempersepsikan Pancasila sebagai sumber dari segala sumber hukum bahwa semua produk hukum tidak boleh bertentangan dengan nilai-nilai yang terkandung dalam Pancasila. Ada yang menjawab bahwa Pancasila harus menjiwai seluruh produk hukum yang ada di Indonesia.

\section{B. Makna Pancasila sebagai Identitas Nasional}

Nasionalisme merupakan suatu
paham yang mengikat sebagian umat
manusia dengan tali solidaritas sekaligus
menciptakan atau mempertegas garis
pemisah antara imagined community yang
baru dengan siapa saja yang dikayalkan
sesuai batasnya. Nasionalisme ialah paham
atau ajaran untuk mencintai bangsa dan
negara sendiri. Dengan kata lain adalah
kesadaran keanggotaan dalam suatu bangsa
yang secara potensial atau aktual bersama -


sama mencapai mempertahankan dan mengabadikan identitas, integritas, kemakmuran dan kekuatan bangsa itu. Nasionalisme menuntut komitmen dari warga negaranya untuk mencintai negaranya baik secara lahiriyah maupun batiniah. Dalam tataran praktis tumbuhnya rasa kebangsaan dan cinta tanah air pada dalam diri individu atau kelompok nasionaslisme dipengaruhi oleh faktor pendorong. Tumbuhnya semangat nasionalisme Indonesia disebabkan adanya persamaan, nasib, tujuan, dan bangsa Indonesia telah lelah akan penjajahan yang telah dilakukan selama ratusan tahun.

Berdasarkan temuan dari informan tentang nasionalisme, sebagian besar Mahasiswa memberikan jawaban bahwa nasionalisme memiliki arti yang penting bagi bangsa Indonesia. Yang nampak dari jawaban hasil wawancara dapat memberikan pengertian yang cukup baik mengenai nasionalisme, yang pada intinya adalah cinta tanah air, bangsa dan siap bela negara. Namun ada beberapa informan yang tidak mengetahui tentang nasionalisme. Mayoritas dapat menjawab bahwa nasionalisme identik dengan mencintai Indonesia meskipun
Negara dalam keadaan apapun. Misalnya krisis ekonomi yang telah melanda bangsa Indonesia, tidak boleh berpengaruh terhadap kecintaan kita kepada tanah air. Artinya nasionalisme dipahami sebagai perasaan yang bangga sebagai bangsa Indonesia dan bertanah air Indonesia sampai kapanpun. Dengan demikian dapat disimpulkan bahwa mahasiswa memang kurang cakap mendefinisikan nasionalisme sesuai kaidah atau pengertian yang berlaku, tetapi persepsi mereka tentang nasionalisme telah mengarah pada pemahaman yang benar, yakni cinta tanah air, semangat bela Negara dan bangga sebagai bangsa Indonesia.

Disisi lain, hasil penelitian menunjukkan bahwa sebagian besar mahasiswa mampu memahami arti dan makna nasionalisme sebagai cinta tanah air, cinta bangsa, dan siap membela negara dalam rangka menjaga keutuhan Negara Kesatuan Republik Indonesia. Dari pandangan mahasiswa tersebut dapat diartikan bahwa mahasiswa memiliki semangat nasionalisme yang cukup tinggi kepada bangsa dan negara Indonesia secara teritorial baik dalam mempertahankan keutuhan Negara Kesatuan Republik 
Indonesia dan secara kebudayaan, tidak rela budaya asli Indonesia di klaim oleh negara lain. Dengan kata lain mencintai Indonesia dalam persepsi mahasiswa tidak sebatas pada wilayah geografis atau territorial semata, melainkan juga hal-hal yang bersifat social, ekonomi dan kebudayaan. Ringkasnya nasionalisme dimata mahasiswa IKIP PGRI Madiun dapat dipahami dengan baik meskipun mayoritas belum bisa mendefiniskan secara konseptual dan akademis.

$$
\text { Idiologi adalah gagasan }
$$

berdasarkan pemikiran sedalam-dalamnya dan merupakan pemikiran filsafat. Idiologi digunakan untuk segala cita-cita, nilai-nilai dasar dan keyakinan-keyakinan yang mau dijunjung tinggi sebagai pedoman normatif.

\section{Berdasarkan hasil wawancara} dengan informan, kebanyakan mahasiswa mengetahui idiologi -idiologi, selain Pancasila, seperti liberalisme-kapitalisme, sosialisme -komunisme, namun belum mampu menjelaskan secara mendalam dan bahkan ada yang tidak tahu sama sekali arti dan makna tentang idiologi - idiologi tersebut. Ideologi-ideologi itu dipandang sebagai paham yang berasal dari luar negeri yang harus disaring untuk bisa dipakai oleh bangsa Indonesia. Mayoritas menjawab tidak anti ideology lain, tetapi harus disesuaikan dengan kepribadian bangsa.

Hasil penelitian tersebut menunjukkan bahwa sebagian besar mahasiswa mengetahui idiologi-idiologi yang berpengaruh besar di dunia ini seperti liberalisme atau kapitalisme, sosialisme dan komunisme. Bangsa Indonesia memiliki idiologi sendiri yaitu Pancasila yang terbukti memiliki keampuhan dan ketangguhan. Artinya berbagai upaya untuk memecahbelah bangsa Indonesia melalui berbagai macam kudeta dan pemaksaan untuk diterapkannya idiologi lain terhadap bangsa Indonesia telah gagal. Hal ini menandakan kesaktian dari idiologi Pancasila.

Dalam implementasi Pancasila sebagian besar mahasiswa menilai bahwa implementasi Pancasila masih belum optimal. Nilai-nilai Pancasila belum diterapkan dalam kehidupan sehari-hari, baik oleh penyelenggara negara maupun dalam kehidupan masyarakat, yang nampak seperti maraknya kasus korupsi, aksi kekerasan dan konflik, gejala disintegrasi 
bangsa, intoleransi. Mayoritas mahasiswa menjawab bahwa pelaksanaan nilai-nilai pancasila belum optimal. Banyak yang menjawab Pancasila harus didorong untuk lebih aplikatif bagi masyarakat Indonesia. Berdasarkan pandangan dari mahasiswa tersebut dapat diartikan bahwa mahasiswa menghendaki agar nilai-nilai Pancasila dapat diterapkan dalam kehidupan sehari-hari dengan memberikan keteladanan dari para pemimpin bangsa dan negara maupun masyarakat. Dengan kata lain untuk lebih membumikan Pancasila. Penerapan nilainilai Pancasila yang konsisten dalam kehidupan bermasyarakat berbangsa dan bernegara akan dapat mewujudkan kehidupan bangsa Indonesia yang adil dan sejahtera damai, dan bermartabat.

\section{Penerapan Pancasila dalam} kehidupan sehari-hari, pada dasarnya sebagian besar mahasiswa memberikan tanggapan bahwa nilai-nilai Pancasila itu harus diterapkan dalam kehidupan seharihari secara konsisten baik oleh pejabat pemerintah dan masyarakat, dan pembudayaannya dapat dimulai sejak pendidikan usia dini. Namun belum sepenuhnya dilakukan secara konsisten dan konsekuen. Dapat diartikan bahwa nilainilai Pancasila lebih diaktualisasikan dalam kehidupan bermasyarakat, berbangsa dan bernegara. Penerapan Pancasila yang konsisten dalam kehidupan sehari-hari oleh seluruh komponen bangsa Indonesia dapat mengatasi kompleksitas atau carut marutnya persoalan yang tengah melanda bangsa saat ini.

Bhinneka Tunggal Ika adalah simbol bangsa dan negara Indonesia yang memiliki arti meskipun bangsa Indonesia bermacam-macam suku, ras, agama dan budaya tetapi tetap satu yaitu Indonesia.

Sebagian besar mahasiswa menilai bahwa Bhinneka Tunggal Ika itu hanya simbol saja dan belum dipahami dan dilaksanakan dengan baik. Hal tersebut nampak dari masih banyaknya konflik dan kekerasan yang berbau SARA, gejala disintegrasi bangsa yang dapat mengancam persatuan bangsa. Dapat diartikan bahwa mahasiswa menginginkan perlu adanya revitalisasi akan peran pentingnya semboyan itu demi keutuhan bangsa. Dengan kata lain keberagaman dan perbedaan di antara masyarakat Indonesia jangan dijadikan alat pemecah belah, namun harus justru 
sebaliknya menjadi sarana bagi bangsa untuk tetap bersatu.

Mengenai eksistensi NKRI sebagian besar mahasiswa berpandangan bahwa eksistensi NKRI sedang terancam keutuhannya terutama oleh negara tetangga Malaysia terkait dengan sengketa perbatasan dan kepulauan. Malaysia kerap kali menyerobot tapal perbatasan antara Indonesia dan Malaysia di Kalimantan. Dan adanya klaim budaya kita oleh negara tersebut. Dan ada juga yang tidak dapat memberikan tanggapan atau tidak mengetahuinya. Persepsi informan tersebut berarti dan bermakna bahwa keutuhan NKRI perlu mendapat perhatian yang serius dan memperhatikan wilayah-wilayah terutama di perbatasan dengan pembangunan infrastruktur yang baik dan pendidikan wawasan kebangsaan. Disamping itu kita harus menghargai budaya sendiri atau cinta budaya sendiri dan merawatnya, agar bangsa lain tidak mengklaim budaya asli Indonesia sebagai warisan luhur bangsa Indonesia

Konstitusi negara Indonesia adalah Undang-Undang dasar 1945, yang disahkan oleh PPKI pada tanggal 18 Agustus 1945. Karena adanya perubahan kehidupan masyarakat baik pengaruh dari luar maupun dari dalam masyarakat itu sendiri, maka konstitusi sebagai landasan kehidupan bernegara harus senantiasa menyesuaikan dengan perkembangan yang terjadi di masyarakat. Oleh karena itu perlu dilakukan amandemen yang artinya perubahan. Mengamandemen artinya mengubah atau mengadakan perubahan. Amandemen Undang-Undang Dasar 1945 yang dimaksudkan untuk mengubah dan memperbaharui konstitusi negara Indonesia agar sesuai dengan prinsip-prinsip negara demokrasi dan menjunjung tinggi Hak Azasi Manusia.

Berdasarkan wawancara dengan informan mengenai Undang-Undang dasar 1945, baik sebelum maupun setelah diamandemen mahasiswa memberikan jawaban sebagai berikut, sebelum diamandemen menurut kebanyakan mahasiswa bahwa UUD 1945, kurang sempurna, misalnya ada yang memberikan penilaian sistem pemerintahan menjadi otoriter. Dan setelah diamandemen empat kali cukup baik, walaupun dalam praktek penyelenggaraan negara dan pemerintahan masih belum sesuai dengan harapan 
masyarakat. Dan ada beberapa mahasiswa yang tidak dapat memberikan penilaian dengan baik, karena tidak memahami perbedaan sebelum dan sesudah di amandemen.

$$
\text { Hasil penelitian tersebut }
$$
menunjukkan bahwa amandemen terhadap Undang-Undang Dasar 1945 harus dilakukan untuk menyempurnakan ketentuan-ketentuan atau isi yang terdapat dalam Undang-Undang Dasar 1945 dalam upaya menyesuaikan perkembangan zaman, karena pada dasarnya konstitusi adalah produk situasi sebagai mana yang dikatakan oleh begawan konstitusi K.C. Wheare : konstitusi adalah resultante alias hasil kesepakatan pembentuknya berdasarkan kesepakatan pembentuknya berdasarkan situasi politik, ekonomi, sosial, budaya (poleksosbud) pada waktu tertentu. Konstitusi adalah produk situasi. karena itu niscaya adanya resultante baru jika memang ada perkembangan situasi dan kebutuhan baru. dalil Wheare tersebut memberi arti bahwa di dunia ini tak ada konstitusi yang tak dapat diubah.

Berdasarkan hasil wawancara mengenai penerapan Pancasila pada setiap rezim pemerintahan, sebagian besar mahasiswa memberikan jawaban bahwa pada umumnya Pancasila pada setiap rezim pemerintahan baik orde lama, orde baru, dan orde reformasi belum dilaksanakan secara optimal.

Hasil penelitian tersebut menunjukkan para mahasiswa menilai bahwa penerapan Pancasila pada tiap rezim yang berkuasa dari orde lama, orde baru dan era reformasi berbeda beda. Pada zaman orde lama Pancasila juga terjadi pengkhianatan dengan munculnya beberapa pemberontakan di beberapa daerah. Pada masa orde baru Pancasila ditafsirkan secara sepihak oleh penguasa dan digunakan alat untuk menopang kekuasaan yang otoriter. Pancasila pada rezim orde baru digambarkan oleh Asad Said Ali Wakil Kepala Badan Intelejen Negara "Pancasila kemudian tersudut, dikeramatkan, dimonopoli, dan dilindungi dengan tindak kekerasan. Pancasila yang keropos itu akhirnya mengalami nasib naas : jatuh tersungkur bersama rezim orde baru ." Sedangkan pada era reformasi, Pancasila cenderung terpinggirkan, berada dalam lorong-lorong sepi tertutup oleh hiruk pikuk, kegaduhan 
politik transaksional. Namun ada temuan yang menarik bahwa pada masa pemerintahan Gus Dur, Pancasila dapat diterapkan lebih baik dengan dihargainya isu tentang pluralisme.

$\begin{array}{rrr}\text { Pluralisme } & \text { adalah } & \text { keadaan } \\ \text { masyarakat yang } & \text { majemuk. } & \text { Menjadi }\end{array}$
kenyataan bahwa masyarakat Indonesia itu terdiri dari berbagai suku bangsa, etnik, ras, budaya dan agama yang beragam dari Sabang sampai Merauke dari Miangas sampai pulau Rote. Semua elemen-elemen masyarakat tersebut memiliki hak dan kewajiban yang sama, kesetaraan dalam kedudukannya sebagai warga negara Indonesia. Tidak membeda-bedakan kelompok minoritas dan mayoritas, golongan kaya dan kurang mampu, semuanya sederajat dihadapan hukum dan pemerintahan.

\section{BAB V}

\section{KESIMPULAN DAN SARAN}

\section{A. Kesimpulan}

1. Persepsi mahasiswa tentang eksistensi Pancasila cukup baik. Terbukti dari mayoritas mahasiswa telah mengetahui dengan jelas silasila dalam Pancasila. Bahkan diantara mereka ada yang bisa menjelaskan lebih lanjut tentang fungsi dan peran Pancasila bagi bangsa dan Negara Indonesia.

2. Sebagian besar mendapat pengetahuan tentang Pancasila dari bangku sekolah dan kuliah karena itu kebanyakan mahasiswa merasa kurang memperoleh wawasan yang mendalam tentang eksistensi Pancasila. Mereka berpandangan perlu adanya terobosan lain agar Pancasila lebih maksimal untuk dipahami dan diimplementasikan dalam kehidupan sehari-hari.

3. Mayoritas mahasiswa menganggap Pancasila memiliki kedudukan yang vital bagi bangsa dan Negara Indonesia. Selain sebagai perekat keutuhan NKRI, Pancasila juga harus dijadikan landasan bagi setiap proses penyelenggaran Negara di semua level mulai di tingkat pusat sampai pemerintahan desa. 
4. Persepsi mahasiswa tentang Pancasila sebagai identitas nasional dipahami sangat beragam dan variatif. Namun ada satu benang merah yang dapat ditarik dari persepsi yang beraneka ragam tersebut. Yakni Pancasila sebagai indentitas nasional merupakan ciri khas yang hanya dimiliki oleh bangsa Indonesia sekaligus sebagai variable pembeda untuk membandingkan bangsa Indonesia dengan bangsa lain di dunia. Pancasila merupakan identitas nasional yang perlu dan harus dilestarikan.

5. Makna Pancasila sebagai identitas nasional bagi mahasiswa IKIP PGRI Madiun juga ditanggapi beragam. Namun ada substansi yang sama yakni bahwa makna Pancasila sebagai identitas nasional merupakan sesuatu yang amat penting dan strategis bagi eksistensi dan percaturan bangsa Indonesia dengan bangsa lain di dunia. Tanpa memiliki Pancasila sebagai identitas nasional, bangsa Indonesia akan kehilangan jati dirinya sebagai bangsa yang besar dan majemuk.

\section{B. Saran}

1. Perlu ada revitalisasi eksistensi Pancasila berikut fungsi dan perannya baik itu sebagai dasar Negara, kepribadian bangsa, pandangan hidup, maupun sebagai identitas nasional dan jati diri bangsa. Revitalisasi bisa dilakukan melalui jalur pendidikan kepada masyarakat luas.

2. Mengingat pentingnya fungsi dan kedudukan Pancasila dalam konteks NKRI, maka perlu ada terobosan untuk menjamin bahwa Pancasila benar-benar telah dipahami dengan benar oleh seluruh komponen bangsa sekaligus diimplementasikan secara maksimal oleh seluruh anak bangsa. Dengan kata lain menanamkan nilainilai Pancasila tidak cukup hanya mengandalkan pada jalur pendidikan formal, namun perlu ada inovasi agar nilai-nilai Pancasila lebih membumi dan aplikatif

3. Media massa sesungguhnya merupakan sarana yang efektif dan strategis untuk penanaman nilai-nilai Pancasila kepada masyarakat luas di luar jalur pendidikan formal. Karena itu perlu ada kerjasama yang sinergis, diantara komponen bangsa untuk menjamin terlaksananya nilainilai Pancasila dalam kehidupan bermasyarakat, berbangsa dan bernegara. 
DAFTAR PUSTAKA

Amin Rais, 2008, Selamatkan

Indonesia, Yogyakarta, ppsk press

Basrowi dan Sukidin,2002, Metode Penelitian Kualitatif, Perspektif Mikro, Surabaya,

\section{Insan Cendekia}

Dedy Mulyana, 2001, Metodologi Penelitian Kualitatif, Bandung, Rosdakarya.

Heri Herdiawanto, Jumanta Hamdayama, 2010, Cerdas, Kritis, dan Aktif,

Berwarganegara, Jakarta,

Erlangga.

Kaelan, 2008, Pendidikan Pancasila, Yogyakarta, Paradigma

Miles and Huberman, 1996, Qualitative Data Analyisis, A Sourcebook of New

Methods, California, Sage Publication.

Parji, 2010, Pengembangan Nilai-

Nilai Integritas Dan Identitas

Nasional Dari

\section{Perspektif}

Pendidikan,Makalah

Seminar

Nasional,Madiun

Rozali Abdullah, 1983, Pancasila Dasar Negara dan Pandangan Hidup Bangsa,

Rajawali, Jakarta.

Syahrial Syarbaini, 2011, Pendidikan

Pancasila, Jakarta, Ghalia Indonesia.

Winarno, 2007, Pendidikan Kewarganegaraan, Jakarta, Bumi Aksara.

Yudi Latif, 2011, Negara Paripurna, Historisitas, Rasionalitas, dan Aktualitas

Pancasila, Jakarta, Gramedia Pustaka Utama.

\section{Media Masa}

Kompas, 28 Maret 2011, Kembali ke Pancasila.

Kompas, 8 Juni 2011, Pancasila dan Nasionalisme Kampus.

Media Indonesia, 1 Oktober 2010, Menjaga Etika Bermasyarakat.

Republika, 27 Mei 2011, Lunturnya Pancasila di Dada Generasi Muda. 